\title{
SANITASI LINGKUNGAN, PEMBERIAN ASI DAN BUDAYA MARUAS MENINGKATKAN RISIKO DIARE PADA BALITA MASYARAKAT BANJAR
}

\author{
Erni Yuliastuti ${ }^{1}$, Tut Barkinah ${ }^{2}$ \\ 1,2 Poltekkes Kemenkes Banjarmasin Jurusan Kebidanan \\ Email : ernirokhadi74@gmail.com
}

\begin{abstract}
Diarrhea is an important health issue because it is the third major contributor to toodler morbidity and mortality in Indonesia (Basic Health Research, 2013). The incidence of diarrhea in Banjar Regency was ranked 2nd after Banjarmasin city. Diarrhea in Martapura Health Center amounted to 306 people, ranked second after the Gambut Health Center, as many as 936 people (Banjar Regency Health Office,2013). Diarrheaas a top 10 most diseases and the highest prevalence occurs in toddlers. The risk of diarrhea related to knowledge, behaviour of exclusive breastfeeding and environmental sanitation. These three factors will interact with human behavior that could have an impact on the incidence of diarrhea. The purpose of this research was to analyze knowledge, exclusive breastfeeding, environmental sanitation and maternal characteristics, culture about maruas with the incidence of diarrhea. This research is an analytic survey type with cross sectional design. The instrument used is a questionnaire containing a list of questions and documenter. The population of the research was mothers who took their children to visit the IMCI Polyclinic at Martapura Health Center in 2016. The sample is the mother who visited the IMCI Polyclinic in the work area of Martapura Health Center and large sample as many as 100 people. Data analysis using the Chi Square Test. The results showed that there was a relationship between the incidence of diarrhea with, exclusive breastfeeding $(\rho=0,013)$ OR $=4,573$, environmental sanitation $(\rho=0,000)$ OR = 16,579 , maruas culture $(\rho=0,020)$ OR $=3,250$. The risk of the highest incidence of diarrhea by environmental sanitation factors is 16,579 risk timesoccur in families with unhealthy home environmental sanitation.
\end{abstract}

Keywords: Diarrhea; Sanitation; Breastfeeding; Culture

Copyright (C) 2019 Jurnal Skala Kesehatan. Politeknik Kesehatan Banjarmasin All rights reserved

\footnotetext{
Corresponding Author :

Erni Yuliastuti,

Poltekkes Kemenkes Banjarmasin Jurusan

Kebidanan Jln H. Mistar Cokrokusumo

Banjarbaru

Email : ernirokhadi74@gmail.com
} 
Abstrak : Diare merupakan masalah kesehatan yang penting karena penyumbang utama ketiga kesakitan dan kematian balita di Indonesia (Riskesdas, 2013). Kejadian diare di Kabupaten Banjar menduduki peringkat ke-2 setelah Kota Banjarmasin. Penyakit diare di Puskesmas Martapura sebesar 306 orang menduduki peringkat kedua setelah Puskesmas Gambut, sebanyak 936 penderita (Dinkes Kabupaten Banjar,2013). Penyakit diare sebagai 10 besar penyakit terbanyak dan prevalensi tertinggi terjadi pada balita. Risiko diare berkaitan dengan pengetahuan, perilaku tentang pemberian ASI eksklusif serta sanitasi lingkungan. Ketiga faktor ini akan berinteraksi dengan perilaku manusia (PHBS) yang bisa berdampak pada kejadian diare.

Tujuan penelitian ini untuk menganalisis pemberian ASI eksklusif, sanitasi lingkungan dan budaya tentang maruas dengan kejadian diare pada balita.

Penelitian ini merupakan survey analitik dengan rancangan cross sectional. Instrumen yang digunakan yaitu kuesioner dan dokumenter. Populasi penelitian adalah ibu yang membawa anaknya berkunjung ke Poliklinik MTBS di Puskesmas Martapura tahun 2016. Sampel adalah ibu yang berkunjung ke Poliklinik MTBS di wilayah kerja Puskesmas Martapura sebesar 100 orang. Analisis data menggunakan Uji Chi Square .

Hasil penelitian didapatkan ada hubungan kejadian diare dengan pemberian ASI eksklusif $(\rho$ $=0,013) \mathrm{OR}=4,573$, sanitasi lingkungan $(\rho=0,000) \mathrm{OR}=16,579$, budaya maruas $(\rho=0,020)$ $\mathrm{OR}=3,250$. Risiko kejadian diare paling tinggi oleh faktor sanitasi lingkungan yakni 16,579 kali berisiko terjadi pada keluarga dengan sanitasi lingkungan rumahnya tidak sehat.

Kata Kunci : Diare; Sanitasi; ASI;Budaya

\section{PENDAHULUAN}

Data Riskesdas menyebutkan berdasarkan karakteristik penduduk, kelompok umur balita adalah kelompok yang paling tinggi menderita diare. Provinsi Kalimanntan Selatan dengan insiden dan period prevalen diare adalah (3,3\% dan 6,3\%). ${ }^{1}$ Penyakit diare merupakan masalah kesehatan yang penting karena penyumbang utama ketiga kesakitan dan kematian balita di Indonesia. Kejadian diare di Kabupaten Banjar menduduki peringkat ke-2 setelah Kota Banjarmasin. Penyakit diare di Puskesmas Martapura, Kabupaten Banjar tahun 2013 sebesar 880 orang menduduki peringkat kedua setelah Puskesmas Gambut, sebanyak 936 penderita. ${ }^{2}$ Kejadian diare di Puskesmas Martapura ini juga terus mengalami peningkatan pada tahun 2014 yakni sebanyak 960 orang penderita. Penyakit diare juga menjadi 10 besar penyakit terbanyak di Puskesmas Martapura Kabupaten Banjar dan prevalensi penyakit diare paling banyak terjadi pada balita. ${ }^{3}$ Pandangan sebagian masyarakat Banjar yang masih beranggapan bahwa anak balita yang mengalami diare menjadi salah satu tanda bertambahnya kepandaian anak dalam perkembangan motorik seperti mulai belajar merangkak, belajar berjalan dan tumbuh gigi. Orang tua tidak merasa khawatir saat anaknya diare karena keadaan yang terjadi pada anaknya dianggap wajar. Para orang tua jarang membawa anaknya untuk berobat karena budaya dimasyarakat tentang "maruas" pada balita masih diyakini sampai sekarang. Keterlambatan dalam memberikan pertolongan pada anak sering menjadi permasalahan karena keadaan balita tersebut menjadi lebih buruk ketika dibawa ke fasilitas kesehatan ( Polindes/ Puskesmas / RS). Kejadian diare pada balita berkaitan dengan perilaku tentang pemberian ASI eksklusif, sanitasi lingkungan dan budaya dimasyarakat tentang maruas. Faktor ini akan berinteraksi dengan perilaku manusia (Perilaku Hidup Bersih dan Sehat) yang bisa berdampak pada kejadian diare. 


\section{BAHAN DAN METODE}

Penelitian ini menggunakan survey analitik. Pengambilan dan pengumpulan data yang terkait dengan penelitian dilakukan dengan menggunakan kuesioner yang diberikan pada orang tua / keluarga yang datang membawa balitanya berobat ke Puskesmas Martapura. Pengumpulan data dilakukan oleh kolektor data yang terdiri dari tim peneliti dibantu oleh 3 orang enumerator. Instrumen yang digunakan dalam penelitian ini adalah kuesioner dan dokumenter .

Populasi penelitian adalah seluruh ibu yang mempunyai balita di wilayah kerja Puskesmas Martapura Kabupaten Banjar tahun 2016. Sampel penelitian ini adalah ibu (keluarga) yang datang membawa balitanya ke Puskesmas Martapura berjumlah 100 orang. Teknik pengambilan sampel pada penelitian ini diambil secara accidental sampling.

Variabel terikat penelitian adalah kejadian diare. Variabel bebas adalah pendidikan, pengetahuan, umur, pekerjaan, ASI eksklusif, sanitasi lingkungan, budaya "maruas".

Analisis data meliputi analisa univariat untuk memperoleh gambaran distribusi dari masing-masing variabel yaitu kejadian diare, pendidikan, pengetahuan, umur, pekerjaan, ASI eksklusif, sanitasi lingkungan, budaya maruas. Analisis bivariat dilakukan dengan uji Chi Square untuk mengetahui adanya pengaruh antara variabel bebas dan variabel terikat dan perhitungan odds ratio $(O R) .^{4}$

HASIL DAN PEMBAHASAN

1. Hubungan Pemberian ASI Eksklusif dengan Kejadian Diare

\begin{tabular}{ccccccc} 
Tabel 1 \\
Hubungan Pemberian ASI Eksklusif dengan Kejadian Diare \\
di Wilayah Kerja Puskesmas Martapura \\
Tahun 2016 \\
\hline \multicolumn{7}{c}{ Kejadian Diare } \\
Pemberian ASI & \multicolumn{7}{c}{ Diare } & \multicolumn{7}{c}{ Tidak Diare } & Jlh & $\%$ \\
Eksklusif & $\mathrm{n}$ & $\%$ & $\mathrm{n}$ & $\%$ & & \\
Tidak Eksklusif & 25 & 86.2 & 4 & 13.8 & 29 & 100 \\
Eksklusif & 41 & 57.7 & 30 & 42.3 & 71 & 100 \\
Total & 66 & 66,0 & 34 & 34,0 & 100 & 100 \\
Uji Chi-Square & $0=0,013$ & OR=7,42 & & & & \\
\hline
\end{tabular}

Tabel 1 menunjukkan kejadian diare lebih sering terjadi pada balita yang tidak mendapat ASI eksklusif $(86,2 \%)$ dibandingkan dengan bayi yang mendapat ASI eksklusif $(57,7 \%)$. Hasil uji statistik dengan uji Chi-Square dengan nilai $\alpha=0,05$ didapatkan nilai $\rho=$ 0,013 berarti ada hubungan yang bermakna antara pemberian ASI Eksklusif dengan kejadian diare pada Balita di Wilayah Kerja Puskesmas Martapura. Nilai OR $=7,432$ berarti balita yang tidak diberikan ASI eksklusif berisiko 7,432 kali lebih besar dibandingkan dengan balita yang diberikan ASI eksklusif.

Kejadian diare pada bayi yang tidak mendapat ASI eksklusif lebih tinggi dibandingkan dengan bayi yang mendapat ASI eksklusif. Hasil ini menunjukkan bahwa bayi yang tidak mendapat ASI eksklusif lebih rentan terhadap diare. Penelitian oleh Lamberti et al yang dilakukan di negara-negara berkembang menunjukkan perbandingan risiko diare pada bayi yang tidak mendapat ASI eksklusif lebih tinggi $(2,65)$ dibanding yang mendapatkan ASI secara eksklusif $(1,26) .{ }^{5}$ Sejalan dengan Ramadhani (2013) yang menunjukkan adanya hubungan antara pemberian ASI eksklusif dengan angka kejadian diare akut. ${ }^{6}$ Hubungan yang sama juga telah dibuktikan oleh Wijayanti (2010) dalam penelitiannya dengan membandingkan kejadian diare bayi 0- 6 bulan dengan ASI eksklusif dan bayi tanpa ASI eksklusif di Puskesmas Gilingan Kecamatan Banjarsari, Surakarta dengan nilai $p=0,000 .{ }^{7}$

Menurut Suradi bayi yang mendapat ASI lebih jarang terkena diare karena adanya zat protektif saluran cerna seperti Lactobacillus bifidus, laktoferin, lisozim, SlgA, faktor alergi,

Vol.10, No.1, Januari 2019 
serta limfosit T dan B. Zat protektif ini berfungsi sebagai daya tahan tubuh imunologik terhadap zat asing yang masuk dalam tubuh. ${ }^{8}$ Hegar dan Sahetapy (2009) menyebutkan bahwa salah satu kandungan unik ASI adalah oligosakarida yang akan menciptakan suasana asam dalam saluran cerna. Suasana asam ini berfungsi sebagai sinyal untuk pertahanan saluran cerna, yaitu SIgA (Secretory Imunnoglobulin A) yang juga terdapat dalam ASI itu sendiri. SIgA dapat mengikat mikroba patogen, mencegah perlekatannya pada sel enterosit di usus dan mencegah reaksi imun yang bersifat inflamasi sehingga diare tidak terjadi. ${ }^{9} \mathrm{Hal}$ ini sesuai dengan penelitian Lely(2011) tentang ASI eksklusif yang mengandung SIgA terhadap risiko diare akut. Penelitian tersebut menggambarkan kejadian diare akut pada bayi dengan ASI eksklusif $34,8 \%$. Angka tersebut lebih rendah dibandingkan kejadian diare akut pada bayi tanpa ASI eksklusif, yaitu $65,2 \% .^{10}$

Memberikan ASI secara eksklusif berarti keuntungan untuk semua bayi, bayi akan lebih sehat, cerdas, dan berkepribadian baik, ibu akan lebih sehat dan menarik, perusahaan , lingkungan dan masyarakat pun akan lebih mendapat keuntungan. ${ }^{7}$

\section{Hubungan Sanitasi Lingkungan dengan Kejadian Diare}

Tabel 2.

Hubungan Sanitasi Lingkungan dengan Kejadian Diare di Wilayah Kerja Puskesmas Martapura Tahun 2016

\begin{tabular}{lrrrrrr}
\hline & \multicolumn{3}{c}{ Kejadian Diare } & \multicolumn{2}{c}{ Total } \\
\cline { 2 - 7 } Sanitasi Lingkungan & \multicolumn{2}{c}{ Diare } & \multicolumn{1}{c}{ Tidak Diare } & Jlh & $\%$ \\
& $\mathrm{n}$ & $\%$ & $\mathrm{n}$ & $\%$ & & \\
Tidak Sehat & 63 & 76.8 & 19 & 23.2 & 82 & 100 \\
Sehat & 3 & 16.7 & 15 & 83.3 & 18 & 100 \\
\multicolumn{1}{c}{ Total } & 66 & 66,0 & 34 & 34,0 & & 100 \\
Uji Chi Square $\rho=0,000$ & \multicolumn{2}{c}{ OR= 16,579} & & & & \\
\hline
\end{tabular}

Hasil uji statistik dengan uji Chi-Square dengan nilai $\alpha=0,05$ didapatkan nilai $\rho=$ 0,000 berarti ada hubungan yang bermakna antara sanitasi lingkungan dengan kejadian diare pada Balita di Wilayah Kerja Puskesmas Martapura. Nilai OR $=16,579$ berarti keluarga balita dengan sanitasi lingkungan rumahnya tidak sehat berisiko 16,579 kali lebih besar dibandingkan dengan keluarga balita dengan sanitasi lingkungan sehat.

Keadaan sanitasi lingkungan yang kurang baik memungkinkan terjadinya berbagai jenis penyakit antara lain diare, kecacingan, dan infeksi saluran pencernakan. Apabila anak menderita infeksi saluran pencernaan, penyerapan zat-zat gizi akan terganggu yang menyebabkan terjadinya kekurangan zat gizi. Seseorang kekurangan zat gizi akan mudah terserang penyakit, dan pertumbuhan akan terganggu. ${ }^{11}$ Hasil penelitian menunjukan balita yang mengalami diare memiliki kondisi sanitasi lingkungan rumah yang tidak sehat. Sesuai dengan teori menjelaskan lingkungan fisik yang kurang baik dapat menjadikan anak terkena diare. Penyakit diare dapat ditularkan melalui: 1) Pemakaian botol susu yang tidak bersih, 2) Menggunakan sumber air yang tercemar, 3) Buang air besar di sembarang tempat, 4) Pencemaran makanan oleh serangga (lalat, kecoa, dan lain-lain) atau oleh tangan yang kotor 12

Penelitian ini sejalan dengan penelitian yang dilakukan oleh Siti (2010), mengenai hubungan sanitasi lingkungan dan faktor budaya dengan kejadian diare pada anak balita didesa Toriyo Bendosari Kabupaten Sukuharjo bahwa ada hubungan yang bermakna antasa sanitasi lingkungan dengan kejadian diare pada anak. Hasil analisa Chi square test diperoleh $p=0,007(p<0,05)$, artinya bahwa ada hubungan yang bermakna antara sanitasi lingkungan dengan kejadian diare. ${ }^{13}$ Penelitian serupa juga dilakukan oleh Karyono (2009) menunjukan bahwa ada hubungan antara faktor sanitasi lingkungan dengan kejadian diare dengan hasil 
analisis regresi logistic diperoleh bahwa nilai signifikansi (sig.) untuk variabel sanitasi lingkungan sebesar 0,021 lebih kecil dari $\alpha(0,05)$ sehingga dapat disimpulkan bahwa terdapat hubungan yang bermakna antara faktor sanitasi lingkungan dengan kejadian diare. ${ }^{14}$

Kondisi lingkungan yang kurang sehat dapat dilihat dari kebiasaan perilaku hidup sehat (PHBS) yang masih minim seperti belum tersedianya jamban sehat,penggunaan sungai sumber air bersih untuk kehidupan sehari-hari (masak, mandi, gosok gigi,cuci tangan, memasak), membuang sampah di sungai, saluran pembuangan air limbah ke sungai. Kebiasaan lainnya yang juga menjadi penyebab semakin tingginya kejadian diare pada balita adalah mencuci tangan sebelum dan sesudah beraktivitas.

Hasil penelitian, penggunaan air mentah atau air sungai yang digunakan masyarakat kurang layak untuk di konsumsi sebagai air minum yang sehat. Air sungai tersebut memiliki kualitas yang buruk dilihat dari warna air yang tidak jernih, air memiliki bau, dan air yang berasa. Sehingga perlu adanya kesadaran masyarakat bahwa air tersebut tidak layak untuk digunakan sebagai air masak maupun air minum untuk keperluan sehari-hari. Apalagi jika air tersebut dikonsumsi oleh balita secara terus menerus bisa berdampak fatal. Salah satunya bisa menyebabkan balita menderita diare. Kualitas air yang layak dikonsumsi adalah bersih/jernih, tidak berbau, dan tidak memiliki rasa.Sebagian besar air yang digunakan masyarakat berkualitas kurang baik. Dikarenakan peggunaan air sungai untuk keperluan sehari-hari, letak sumur sangat dekat dengan rawa-rawa, pembuangan sampah, baik itu sisa air cuci piring ataupun air cuci pakaian kotor. Oleh sebab itu, untuk memutus rantai penularan diare, sebaiknya menyediakan air bersih yang memenuhi syarat kesehatan termasuk pula letak sumber air bersih untuk mencegah terjadinya pencemaran berkelanjutan.

Sarana air bersih dalam kehidupan sehari-hari yang digunakan sebagai minum, memasak, membersihkan atau mencuci, mandi, wajib memenuhi syarat kualitas dan syarat fisik agar vektor penyakit yang dapat berkembang biak atau dapat menularkan melalui air dapat dikurangi hususnya pada penyakit diare sehingga angka kesakitan penyakit diare menurun. ${ }^{15}$ Kualitas air rumah tangga yang baik harus memenuhi beberapa syarat antara lain syarat fisis, syarat kimiawi, dan syarat bakteriologis. Syarat fisis air rumah tangga yaitu harus jernih, tidak berwarna, tidak berasa, tidak berbau. Syarat kimiawi adalah tidak mengandung zat-zat yang berbahaya untuk kesehatan seperti zat-zat racun, serta tidak mengandung mineral mineral serta zat organik lebih tinggi dari jumlah yang ditentukan. Syarat Bakteriologi air tidak boleh mengandung bibit penyakit yang sering menular dengan perantaraan air adalah penyakit yang tergolong dalam golongan water borne diseases, salah satunya seperti penyakit diare.$^{16}$

Bakteri coliform adalah golongan bakteri intestinal, yaitu hidup didalam saluran pencernaan manusia. Bakteri coliform adalah bakteri indikator keberadaan bakteri patogenik lain. Lebih tepatnya, bakteri coliform fekal ialah bakteri indikator adanya pencemaran bakteri patogen. Penentuan coliform fekal menjadi indikator pencemaran dikarenakan jumlah koloninya pasti berkorelasi positif dengan keberadaan bakteri patogen. Selain itu, mendeteksi coliform jauh lebih murah, cepat, dan sederhana dari pada mendeteksi bakteri patogenik lain. Contoh bakteri coliform adalah, Escherichia coli dan Enterobacter aerogenes. Jadi, keberadaan bakteri coliform ditandai dengan air yang berwarna, berbau dan berasa. Makin sedikit kandungan bakteri coliform pada air, maka air tidak berawarna berbau dan tidak berasa. ${ }^{17}$

Penelitian lain yang dilakukan oleh Zubir (2006) menyimpulkan bahwa selain sumber air minum tempat pembuangan tinja juga merupakan sarana sanitasi yang penting dalam mempengaruhi kejadian diare. Membuang tinja yang tidak memenuhi syarat sanitasi dapat mencemari lingkungan pemukiman, tanah dan sumber air. Dari lingkungan yang tercemar tinja terakumulasi dengan prilaku manusia yang tidak sehat, tidak mencuci tangan dengan sempurna setelah bekerja atau bermain di tanah (anak-anak), melalui makanan dan minuman maka dapat menimbulkan kejadian diare. ${ }^{18}$ Pembuangan tinja yang tidak memiliki syaratsyarat kesehatan dapat memberikan peluang untuk berkembang biaknya serangga, lalat, tikus, mencemarkan sumber air minum, mencemarkan lingkungan hidup, dan akan mudah terjadinya penyebaran penyakit seperti diareoleh karena itu pembuangan tinja harus memenuhi persyaratan kesehatan kesehatan. ${ }^{19}$

Vol.10, No.1, Januari 2019 
3. Hubungan Budaya "Maruas" dengan Kejadian Diare

Tabel 3

Hubungan Budaya Maruas dengan Kejadian Diare di Wilayah Kerja Puskesmas Martapura

Tahun 2016

\begin{tabular}{|c|c|c|c|c|c|c|}
\hline \multirow{3}{*}{ Budaya Maruas } & \multicolumn{4}{|c|}{ Kejadian Diare } & \multicolumn{2}{|c|}{ Total } \\
\hline & \multicolumn{2}{|c|}{ Diare } & \multicolumn{2}{|c|}{ Tidak Diare } & \multirow[t]{2}{*}{ Jlh } & \multirow[t]{2}{*}{$\%$} \\
\hline & $\mathrm{n}$ & $\%$ & $n$ & $\%$ & & \\
\hline Percaya & 33 & 80.5 & 8 & 19.5 & 41 & 100 \\
\hline Tidak Percaya & 33 & 55.9 & 26 & 44.1 & 59 & 100 \\
\hline Total & 66 & 66,0 & 34 & 34,0 & 100 & 100 \\
\hline Uji Chi Square $\rho=$ & & $\mathrm{OR}=$ & 50 & & & \\
\hline
\end{tabular}

Hasil uji statistik dengan uji Chi-Square dengan nilai $\alpha=0,05$ didapatkan nilai $\rho=$ 0,020 berarti ada hubungan yang bermakna antara budaya maruas dengan kejadian diare pada Balita di Wilayah Kerja Puskesmas Martapura. Nilai OR $=3,250$ berarti keluarga balita yang mempercayai budaya "maruas" berisiko 3,250 kali lebih besar dibandingkan keluarga balita yang tidak mempercayai budaya "maruas".

Budaya yang dikembangkan oleh manusia akan berimplikasi pada lingkungan tempat kebudayaan itu berkembang. ${ }^{20}$ Masyarakat Banjar masih menganut budaya tentang maruas yang dianggap hal yang wajar dialami seorang balita yang sedang mengalami pertumbuhan dan perkembangan. Maruas sebenarnya merupakan kejadian diare yang dialami oleh balita. Namun keadaan ini dianggap hal yang wajar karena merupakan suatu proses yang dilalui oleh balita untuk bertambah kemampuan motoriknya (seperti dari merangkak sampai berjalan) dan akan sembuh dengan sendirinya tanpa harus diobati. Walaupun pada hasil penelitian sebagian besar ibu tidak percaya dengan budaya maruas tetapi dari anggota keluarga yang lain bisa saja masih mempercayai budaya maruas tersebut sehingga berimplikasi dengan kejadian diare.

Dengan demikian dapat dikatakan, bahwa kebudayaan yang berlaku dan dikembangkan dalam lingkungan tertentu berimplikasi terhadap pola tata laku, norma, nilai dan aspek kehidupan lainnya yang akan menjadi ciri khas suatu masyarakat dengan masyarakat lainnya. ${ }^{21}$

\section{KESIMPULAN DAN SARAN}

Sebagian besar (71\%) balita mendapatkan ASI eksklusif. Keluarga balita sebagian besar (82\%) tinggal dengan sanitasi Ingkungan tidak sehat. Dan sebanyak 59 orang (59\%) ibu balita tidak percaya dengan budaya "maruas". Ada hubungan antara pemberian ASI eksklusif, sanitasi lingkungan dan budaya "maruas".Sanitasi lingkungan tidak sehat memiliki risiko paling tinggi $(O R=16,579)$ terjadi diare pada balita. Pemberian ASI yang tidak eksklusif memiliki risiko diare pada balita dengan $\mathrm{OR}=7,42$. Budaya maruas yang dipercaya oleh keluarga balita memilki risiko kejadian diare dengan nilai $\mathrm{OR}=3,25$. Disarankan bagi pihak Puskesmas Martapura untuk lebih meningkatkan penyuluhan tentang Perilaku Hidup Bersih dan Sehat (PHBS) tentang sanitasi lingkungan tempat tinggal dan cuci tangan yang baik dan benar menggunakan sabun dan penggunaan air bersih serta penyediaan air minum yang sehat, agar ibu dapat menerapkan dalam kehidupan sehari-hari serta dapat mengajarkan kepada balitanya sehingga dapat mencegah penyakit diare. 


\section{UCAPAN TERIMAKASIH}

Penulis menyampaikan terimakasih kepada Poltekkes Kemenkes Banjarmasin atas bantuan dana yang diberikan hingga penelitian ini dapat diselesaikan sesuai waktunya.

\section{DAFTAR PUSTAKA}

1. Badan Penelitian dan Pengembangan Kesehatan Kemenkes RI., Riskesdas 2013, Jakarta. 2013.

2. Dinas Kesehatan Provinsi Kalsel, Laporan Diare Kabupaten/Kota Provinsi Kalimantan Selatan, Banjarmasin, 2013.

3. Dinas Kesehatan Kabupaten Banjar, Laporan diare Kabupaten/Kota Kabupaten Banjar. Kalimantan Selatan,. Kabupaten Banjar, 2013.

4. Hidayat AAA., Metode Penelitian Kebidanan dan Teknik Analisa Data, Jakarta,Salemba Medika, 2012.

5. Lamberti, Laura M et al. "Breastfeeding and the risk for diarrhea morbidity and mortality", (diunduh 10 November 2018),Tersedia dari URL:HYPERLINK http: //www.biomedcentral.com/1471-2458/11/S3/S15, 2011.

6. Rahmadhani,E.P.,Lubis G.,Edison,"Hubungan Pemberian ASI Eksklusif dengan Angka Kejadian Diare Akut pada Bayi Usia 0-1 Tahun di Puskesmas Kuranji Kota Padang", http://jurnal.fk.unand.ac.id. Jurnal Kesehatan Andalas. 2013.

7. Wijayanti, Winda, "Hubungan antara Pemberian ASI Eksklusif dengan Angka Kejadian Diare pada Bayi Umur 0-6 Bulan di Puskesmas Gilingan Kecamatan Banjarsari Surakarta", Skripsi, Universitas Sebelas Maret, Surakarta, 2010.

8. Suradi, Rulina, Manfaat ASI dan Menyusui. Jakarta: Fakultas Kedokteran Universitas Indonesia. 2008.

9. Hegar, Badriul dan Magdalena Sahetapy, "Air Susu Ibu dan Kesehatan Saluran Cerna", (diunduh 2 November 2017). 2009, Tersedia dari URL:HYPERLINK http: /www.idai.or.id/asi/artikel.asp?q=20091029105942

10. Lely, "Peran ASI Eksklusif yang Mengandung Antibodi SIgA terhadap Risiko Diare Akut pada Bayi Usia 1-6 Bulan" 2011 (diunduh 25 Februari 2012) Tersedia dari

URL:HYPERLINK http: //www.pps.unud.ac.id/disertasi

11. Vivian, Asuhan Neonatus Bayi dan Anak Balita. Salemba Medika, Jakarta, 2012.

12. Depkes, RI., Pedoman Pemberantasan Penyakit Diare. Jakarta : Ditjen PPM dan PL., 2005.

13. Siti A., "hubungan sanitasi lingkungan dan faktor budaya dengan kejadian diare pada anak balita di desa toriyo kecamatan bendosari kabupaten sukoharjo."Nurseline Journal Vol.1 No.1,Mei ,2016 http://jurnal.unimus.ac.id/index.ph p/psn12012010/article/view/52

14. Karyono., Basirun., \& Septiwi, C. "Faktor-Faktor Yang Mempengaruhi Kejadian Pasien Diare Pada Anak Di Rsud Majenang Kabupaten Cilacap Tahun 2008”, Jurnal Ilmiah Kesehatan Keperawatan, 5 (1), 2009.

15. Agus, S., Handoyo,. \& Widiyantis, D.A.K, Analisis Faktor-Faktor Resiko Yang Mempengaruhi Kejadian Diare Pada Balita Di Puskesmas Ambal 1 Kecamatan Ambal Faktor-Faktor Yang Berhubungan Dengan Kejadian Diare Kabupaten Kebumen. "Jurnal Ilmiah Kesehatan Keperawatan, 5 (2), 2009.

16. Depkes RI, Perilaku Hidup Bersih Dan Sehat,Jakarta : Depkes RI. 2010.

17. Kemenkes RI., Kurikulum dan Modul Pelatihan Sanitasi Total Berbasis Masyarakat (STBM), Jakarta Kementerian Kesehatan RI; 2014.(Online),

18. Zubir, Juffrie, M., Dan Wibowo, T. Faktor-Faktor Risiko Kejadian Diare Akut Pada Anak 0-35 Bulan (Batita) Di Kabupaten Bantul, Sains Kesehatan.Vol 19. No 3. Januari 2016. Issn 1411-6197: 319-332; 2006.

19. Saktiansyah, 'Hubungan Sanitasi Lingkungan dengan Kejadian Penyakit Diare pada Masyarakat Kawasan Pesisir Kelurahan Nambo Kecamatan Abeli Kota Kendari." Skripsi. Universitas Haluoleo, Kendari, 2010.

20. Nasili, Thaha, RM dan Seweng, A., Perilaku pencegahan diare anak balita di 
wilayah bantaran kali Kelurahan Bataraguru Kecamatan Wolio Kota Bau-Bau, Universitas Sulawesi Tenggara, 2011.

21. Sander, M.A, Hubungan Faktor Sosial Budaya dengan Kejadian Diare di Desa Candinegoro Kecamatan Winoayu Sidoarjo, Jurnal Medika, Vol 2, No.2 Juli- Desember 2005 :163-193, 2005 